\title{
Bio-Flocculation Property Analyses of Oleaginous Microalgae Auxenochlorella protothecoides UTEX 2341
}

\author{
Jinyu Li, Baozhen Li and Jinshui Yang *D \\ State Key Laboratory of Agrobiotechnology, College of Biological Sciences, China Agricultural University, \\ Beijing 100193, China; jinyuli2014@cau.edu.cn (J.L.); bzhli@cau.edu.cn (B.L.) \\ * Correspondence: yangjsh1999@163.com; Tel.: +86-10-6273-3464; Fax: +86-10-6273-3349
}

Citation: Li, J.; Li, B.; Yang, J.

Bio-Flocculation Property Analyses of Oleaginous Microalgae Auxenochlorella protothecoides UTEX 2341. Sustainability 2021, 13, 2885. https://doi.org/10.3390/su13052885

Academic Editor: Guijin Su

Received: 26 January 2021

Accepted: 2 March 2021

Published: 7 March 2021

Publisher's Note: MDPI stays neutral with regard to jurisdictional claims in published maps and institutional affiliations.

Copyright: (c) 2021 by the authors. Licensee MDPI, Basel, Switzerland. This article is an open access article distributed under the terms and conditions of the Creative Commons Attribution (CC BY) license (https:// creativecommons.org/licenses/by/ $4.0 /)$.

\begin{abstract}
The bio-flocculation ability of UTEX 2341 was studied for the purpose of improving microalgae harvesting efficiency to cut the high cost of biofuel production. The algae cells of UTEX 2341 cultured under heterotrophic and municipal wastewater conditions were found to have better self-flocculation ability, with flocculation rates of $92 \%$ and $85 \%$ at $2 \mathrm{~h}$, respectively. Moreover, the flocculation rates of 16 freeze-dried microalgae powder samples cultured under different stress conditions were $0 \sim 72 \%$ with an algae powder dosage of $35 \mathrm{mg} \mathrm{L}^{-1}$. The flocculation efficiency of DIM, DCd1, DT28, and L6S was stable under different $\mathrm{pH}$ of $3 \sim 9$ and temperatures of $15 \sim 50{ }^{\circ} \mathrm{C}$. For samples of IM, LCd0.6, LMn2, and LZn2, the flocculation efficiency decreased or increased respectively with increased $\mathrm{pH}$ or temperatures. Though the flocculation properties of the eight samples showed wide differences, their flocculant compositions were almost the same with unknown components occupying large proportions. More studies needed to be further carried out to reveal the flocculation mechanisms and analyze the flocculation abilities in practical application, which would be conducive to future large-scale application of the bio-flocculation method and also cost reduction.
\end{abstract}

Keywords: Auxenochlorella protothecoides; wastewater; self-flocculation; bio-flocculation; biofuel

\section{Introduction}

Compared with terrestrial plants, oil-rich microalgae are regarded as a much better and one of the most promising feedstocks for biodiesel production for their fast growth rate and high lipid content $[1,2]$. They may also have great potential in meeting the everincreasing global demand for renewable and environmentally friendly energy as they can be cultivated in brackish water/wastewater on non-arable land. However, the harvesting and dewatering process contribute more than $20 \%$ to the total cost of biofuel production. The small algae size (about $5-50 \mu \mathrm{m})$, low biomass concentration $\left(0.5-5 \mathrm{~g} \mathrm{~L}^{-1}\right)$, and negative surface charged (about -7.5 to $-40 \mathrm{mV}$ ) make it difficult to separate microalgae from its medium [3-5]. Therefore, there is an urgent need to develop effective and economical biomass harvesting technologies in the industrialization process of microalgae oil production.

Currently, physical, chemical, and bio-flocculation are the most commonly used harvesting methods. Though physical and chemical flocculation methods are widely used for harvesting algae, they are either highly energy-consuming or time-consuming or may lead to secondary pollution in downstream biofuel extraction and refinery processes [5-9]. There are two types of bio-flocculation, active flocculation (also named self-flocculation) and passive flocculation. Self-flocculation occurs naturally in certain microalgae, including Skeletonema, Ankistrodesmus flcatus, Nannochloropsis, S.obliquus, Ettlia texenssi, Scenedesmus obliquus, and Tetraselmis, some of which had been applied in non-flocculation microalgae harvesting, but until now, only a few species of microalgae have been reported to be able to self-flocculate [5,10-12]. Passive flocculation is a method using microorganisms, usually bacteria, fungi, or algae $[13,14]$, or their metabolites to flocculate other non-flocculation microalgae. The metabolites of algal organic matter (AOM) are substances carried on the 
surface of algae cells and are mainly constituted of extracellular polysaccharide substances (EPS), a mixture of polysaccharides, proteins, lipids, glycolipids, glycoproteins, and nucleic acids [15]. Rashid et al. found that microalgae species showed distinct flocculation mechanisms due to variations in their EPS characteristics [16]. The recovery rates of $C$. vulgaris accompanying self-flocculating microalgae Ettlia texensis, Ankistrodesmus falcatus, and Scenedesmus obliquus increased from $25 \%$ to $40 \%, 36 \%$ and $31 \%$ at a ratio of $4: 1$ after 3 hours' sedimentation. The addition of Tetraselmis suecica to Neochloris oleoabundans increased the flocculation efficiency from $40 \%$ to $50 \%$ [12]. The flocculation efficiency of $C$. vulgaris CNW11 with self-flocculating Chlorella vulgaris JSC-7 added was 80\% [17]. Harvesting microalgae by bio-flocculation could reduce the costs and be applied on a large-scale.

The microalgae of Auxenochlorella protothecoides UTEX 2341 is easy to cultivate and has a fast growth rate. UTEX 2341 could grow under autotrophic, heterotrophic, and wastewater conditions, and responded well to stress treatment, such as heavy metals of cadmium, manganese, and zinc ions, low or high temperatures, and addition of $\mathrm{NaCl}$. The lipid content of UTEX 2341 under the above stresses increased from 10\% to 35\% [18-20] but the harvesting process of UTEX 2341 remained the hardest part, so the bio-flocculation properties of UTEX 2341 should be primarily analyzed.

\section{Materials and Methods}

\subsection{Algal Growth Conditions}

Microalgae strain A. protothecoides UTEX 2341 were cultivated at $25{ }^{\circ} \mathrm{C}$ in a heterotrophic improved medium (IM) [18]. Then they were incubated in an orbital shaker at $140 \mathrm{rpm}$ and illuminated at $50 \mu \mathrm{mol} \mathrm{m} \mathrm{m}^{-2} \mathrm{~s}^{-1}$ photosynthetic active radiation (PAR) provided by cool white fluorescent tubes in a 12:12 L:D cycle for $48 \mathrm{~h}$ as seed cells were reaching the mid-log phase. Then they were inoculated into a $500 \mathrm{~mL}$ Erlenmeyer flask containing $200 \mathrm{~mL}$ medium at a ratio of $10 \%$ and a shaking speed of $140 \mathrm{rpm}$ at $25^{\circ} \mathrm{C}$ in a 12:12 L:D cycle for seven days. The $\mathrm{pH}$ of the medium was monitored every $24 \mathrm{~h}$. And the self-flocculation of algae was analyzed after four and seven days of cultivation at time intervals of $0.5,1,1.5$, and $2 \mathrm{~h}$. The biomass and lipid content of algae cultured for four and seven days were also measured.

The municipal water (obtained from the influent of Beijing Xiaojia River Sewage Treatment Co., Ltd., Beijing, China) had a chemical oxygen demand (COD) of $220 \mathrm{mg} \mathrm{L}^{-1}$ and no suspended solids. It was immediately used without sterilization. The live algae cells cultured for four days in IM medium were centrifugated at $7156 \times g$ for $5 \mathrm{~min}$ and washed twice by deionized water. Then samples of wet algae cells with a respective cell dry weight of $0.425 \mathrm{~g}$ (low), $1.06 \mathrm{~g}$ (medium), and $3.34 \mathrm{~g}$ (high) were incubated into $200 \mathrm{~mL}$ municipal wastewater and cultured for $168 \mathrm{~h}$. The algae cells were examined every $24 \mathrm{~h}$ until $168 \mathrm{~h}$ and the corresponding ammonia nitrogen content of the wastewater was monitored [21]. After seven days of cultivation, the self-flocculation rate of algae was tested at time intervals of $0.5,1,1.5$, and $2 \mathrm{~h}$.

\subsection{The Details of Freeze-Dried Algae Samples for Bio-Flocculation Analysis}

A total of 16 dried algal powder samples preserved in our laboratory were analyzed for their bio-flocculation abilities (Supplemental Table S1) $[18,19]$. These algae were cultured in IM medium under different stress conditions (with/without light, with different heavy metal stress, with $\mathrm{NaCl}$ stress, with different culture temperature) for $168 \mathrm{~h}$, then harvested by centrifuging at $7156 \times g$ for $5 \mathrm{~min}$, and freeze-dried for two days and preserved in valve bags. The biomass, lipid content, and other details of these 16 algae samples were listed in Supplemental Table S1.

\subsection{Evaluation of Microalgae Flocculation Ability}

2.3.1. The Self-Flocculation Analysis of Algae

Forty milliliters of homogeneous microalgae suspensions were sedimented by gravity in $100 \mathrm{~mL}$ beakers at time intervals of $0,0.5,1,1.5$, and $2 \mathrm{~h}$, and the corresponding OD680 
were measured by spectrophotometer. The wavelength of 680 (OD680) was checked because UTEX 2341 had a maximum absorbance in this wavelength. The flocculating rates were calculated according to the following equation:

$$
\text { Self-flocculating rate }(\%)=\left(1-\text { OD } 680 t / \mathrm{OD} 60 \mathrm{t}_{0}\right) \times 100 \%
$$

where OD $680 \mathrm{t}$ was the absorbance of algae at $0.5,1,1.5$, and $2 \mathrm{~h}$. OD $680_{0}$ was the absorbance of algae at the $0 \mathrm{~h}$.

\subsubsection{Bio-Flocculation Analysis of Freeze-Dried Algae Powder}

The flocculating rates of microalgae samples were measured by using Liu's method [22], with a minor modification that a certain amount of algae powder resuspended by deionized water was added into $40 \mathrm{~mL}$ of kaolin clay suspension with a concentration of $5 \mathrm{~g} \mathrm{~L}^{-1}$. The effects of different algae dosages $\left(0-35 \mathrm{mg} \mathrm{L}^{-1}\right)$ were examined. The flocculating rate was calculated according to the following equation:

$$
\text { Flocculating rate }(\%)=(1-\mathrm{A} / \mathrm{B}) \times 100 \%
$$

where B was the absorbance of the control and A was the absorbance of the sample at $550 \mathrm{~nm}$. The effects of $\mathrm{pH}$ and temperatures on the bio-flocculation abilities were analyzed. The $\mathrm{pH}$ value of the algae-kaolin clay suspension was adjusted by $1 \mathrm{M}$ of hydrochloric acid or $1 \mathrm{M}$ of sodium hydroxide in the $\mathrm{pH}$ range of $3-10$. The temperature range was $15-50{ }^{\circ} \mathrm{C}$.

\subsection{The Composition Analysis of Flocculant}

In addition, the flocculant constitution was analyzed. $10 \mathrm{mg}$ freeze-dried algae powder of selected microalgae samples were dissolved in $10 \mathrm{~mL}$ deionized water, mixed well with an oscillator, and centrifuged at $7156 \times g$ for $5 \mathrm{~min}$. Then the supernatant was collected. The polysaccharide and the protein in the supernatant were respectively measured by the methods using phenol-sulfate [23] and coomassie brilliant blue [24].

\subsection{The Analysis of Biomass and Lipid Content of UTEX 2341}

The biomass of UTEX 2341 cultured under heterotrophic and municipal wastewater conditions was analyzed after centrifugation and freeze-drying. The lipid content was measured using chloroform: methanol. The details could be referred to from Xing et al. [19].

\subsection{Statistical Analysis}

All experiments were performed using biological triplicates to ensure reproducibility. Values presented were means \pm SD. Statistical analyses were carried out using the SPSS statistical package. Differences were considered statistically significant at $p$ values $<0.05$.

\section{Results and Discussion}

3.1. The Growth and Self-Flocculation Analysis of UTEX 2341 Cultured in Heterotrophic Medium and Municipal Wastewater

The algae cells were cultured under heterotrophic conditions and the medium $\mathrm{pH}$ changed with the culture time. As was shown in Figure 1a, the $\mathrm{pH}$ changed from the initial 6.0 to 3.9 in four days and then increased slightly to 4.3 on the seventh day. Both the biomass and lipid content of the algae cultivated for four or seven days did not exhibit any significant changes, with the biomass was $5.8 \mathrm{~g} \mathrm{~L}^{-1}$ (Figure $1 \mathrm{~b}$ ). The self-flocculating efficiency of UTEX 2341 within 0 to $2 \mathrm{~h}$ ranged from $53.87 \%$ to $92.82 \%$ after four days of culturing and from $45.80 \%$ to $92.82 \%$ after seven days of culturing (Figure 1c). It showed that the algae cultured under heterotrophic conditions had self-flocculation ability. 

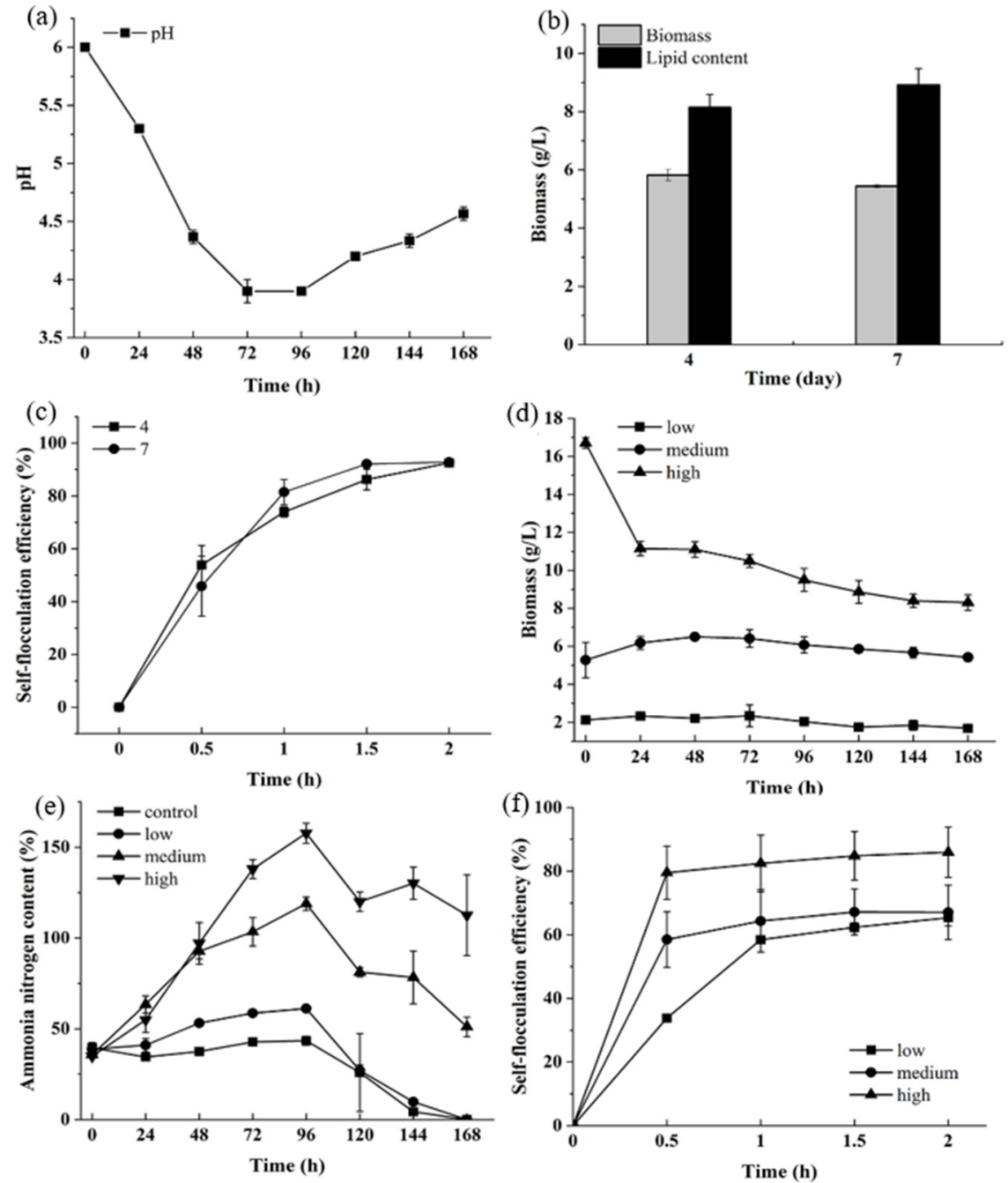

Figure 1. Growth and self-flocculation analysis of UTEX 2341 cultured under heterotrophic and municipal wastewater (a) The pH changes of UTEX 2341; (b) The biomass and lipid content of UTEX 2341 cultured for 4 and 7 days; (c) Self-flocculation efficiency of UTEX 2341 cultured for 4 and 7 days; (d) Biomass changes of UTEX 2341 in municipal wastewater with low, medium and high algae inoculation; (e) Changes of ammonia nitrogen content in municipal wastewater with different dosage of algae; (f) Self-flocculation efficiency of UTEX 2341 cultured in municipal wastewater.

UTEX 2341 cultivated in municipal wastewater became small and decrepit and the algae biomass decreased (Figure 1d). It was reported that biomass productivity of Chlorella sp. was $5.2 \mathrm{~g} \mathrm{~m}^{-2}$ day $^{-1}$ in sludge concentrate with COD of $130 \mathrm{mg} \mathrm{L}^{-1}$ [25]. The biomass of the algal consortium consisting primarily of Chlorella spp., Chlamydomonas and Stichococcus was $5.0 \mathrm{~g} \mathrm{~m}^{-2} \mathrm{day}^{-1}$ in swine wastewater with a COD of $1045 \mathrm{mg} \mathrm{L}^{-1}$ [26]. The biomass concentration of Chlorella vulgaris could reach $3.96 \mathrm{~g} \mathrm{~L}^{-1}$ in swine wastewater treatment with an initial COD of $20,180 \mathrm{mg} \mathrm{L}^{-1}$ [27]. The biomass productivity of $A$. protothecoides UMN 280 and $A$. protothecoides UTEX 2341 was $1.51 \mathrm{~g} \mathrm{~L}^{-1} \mathrm{~d}^{-1}$ and $2.14 \mathrm{~g} \mathrm{~L}^{-1} \mathrm{~d}^{-1}$ cultured in concentrated municipal wastewater with COD of $2344 \mathrm{mg} \mathrm{L}^{-1}$ and in artificial wastewater, respectively [18]. Therefore, the COD in wastewater could be used as a carbon source for algae growth. However, the algae species and nutrient constitution of the wastewater should also be considered. The ammonia nitrogen $\left(\mathrm{NH}_{4}^{+}-\mathrm{N}\right)$ content of the control and the sample with low inoculation dosage decreased after $96 \mathrm{~h}$. In contrast, the $\mathrm{NH}_{4}^{+}-\mathrm{N}$ increased with medium and high inoculation dosage (Figure 1e). The self-flocculation of UTEX 2341 in municipal wastewater at time intervals of $0-2 \mathrm{~h}$ increased from $33 \%$ to $85 \%$. 
Compared with other research, UTEX 2341 had a relatively higher flocculating rate, shorter flocculation time and required no addition of chemical coagulant aid (Table 1).

Table 1. Comparison of flocculation ability of algae.

\begin{tabular}{cccc}
\hline Algae Species & Flocculating Rate & Flocculation Time (h) & References \\
\hline A. protothecoides UTEX 2341 & $92.82 \%(\mathrm{IM})$ & 2 & This study \\
Chaetoceros minutissimus & $85 \%$ & 2 & This study \\
C. vulgaris & (municipal wastewater) & 4 & {$[28]$} \\
N. oleoabundans & $82 \%$ & 3 & {$[12]$} \\
Ettlia sp. & $25 \%$ & 3 & {$[12]$} \\
(Alkaline flocculation added) & $40 \%$ & 2 & {$[16]$} \\
Neochloris oleoabundans & $61 \%$ & 7.5 & {$[29]$} \\
Skeletonema Costatum (pH =10) & $97.4 \%$ & 3 & {$[30]$} \\
Desmodesmus sp. F51 & $65 \%$ & 6 & {$[31]$} \\
Skeletonema marinoi to N. oculata & $60-89 \%$ & & {$[32]$} \\
\hline
\end{tabular}

The decreases in the $\mathrm{pH}$ of the heterotrophic medium of UTEX 2341 might have been caused by some matter secreted into the medium. Moreover, it is widely known that microalgae produce polysaccharides (PSAs) under nutritious stress conditions. Different microalgae species have different self-flocculation mechanisms due to variations in their PSAs characteristics [16]. Self-flocculation of live algae cells of UTEX 2341 was detected; however, whether freeze-dried algae cells of UTEX 2341 under different cultivation conditions would show similar bio-flocculation properties needed to be further verified.

\subsection{Bio-Flocculation Ability Analysis of Freeze-Dried Algae Powder of UTEX 2341}

The bio-flocculation properties of 16 freeze-dried algae powder samples were analyzed, which showed different flocculation abilities. As shown in Figure 2, the bioflocculation rates of these freeze-dried algae powders of UTEX 2341 under different culture conditions ranged differently from $0 \%$ to $70.83 \%$ with an algae powder dosage of $35 \mathrm{mg} \mathrm{L}^{-1}$. In general, the flocculation efficiency of the samples cultured with light (Figure 2a) was higher than that of the samples cultured in dark (Figure 2b). Light could affect the electronic transition of amide bonds in protein, tryptophan, and tyrosine substances, and carboxyl, carbonyl, and lipid substances s [33]. It has been confirmed that light could improve the EPS production in S. meliloti, Anabaena sp. and Porphyridium cruentum [34,35]. In this study, it was also found that light could improve the flocculation efficinency of $A$. protothecoides UTEX 2341. This might be related to the changes in EPS content or composition under light. These results indicated that freeze-dried algae powder also has bio-flocculation abilities and could be used as flocculants to flocculate non-flocculation algae. Heavy metal stressed samples of LMn4, LMn6, LZn4, and LZn6 showed high flocculation efficiency, but the need of high heavy metal content in cultivation process would result in environmental pollution problems and subsequent processing burdens. The bio-flocculation efficiency strongly depended on the microalgae species and flocculant types. Hanumanth et al. reported that the algal organic matter, which is comprised of hydrophilic polysaccharides, hydrophobic proteins and other soluble microbial products, had important impact on the separation efficiency and the AOM compositions were differences in C. vulgaris, M. homosphaera and $M$. aeruginosa [36]. The flocculating rate of C. vulgaris was $82.8 \%, 80.7 \%$, and $80.45 \%$ with 30,40 , and $50 \mathrm{mg} \mathrm{L}^{-1}$ dosage of the purified flocculant excreted by bacterial Shinella albus xn-1 [6]. A 7000-8000 $\mathrm{mg} \mathrm{L}^{-1}$ dosage of flocculant was produced by Paenibacillus sp. AM49 flocculated C. vulgaris at a rate above $90 \%$ [37]. A $100 \mathrm{mg} \mathrm{L}^{-1}$ dosage of proteins produced from Saccharomyces bayanus var. uvarum was needed to flocculate microalgae Chlamydomonas and the rate was 95\% [38]. Based on the comprehensive consideration of biomass, lipid content (Supplemental Table S1), and bio-flocculation ability, eight samples of IM, LCd0.6, 
LMn2, LZn2, DIM, DCd1, DT28, and L6S were selected and their flocculation properties were further analyzed.

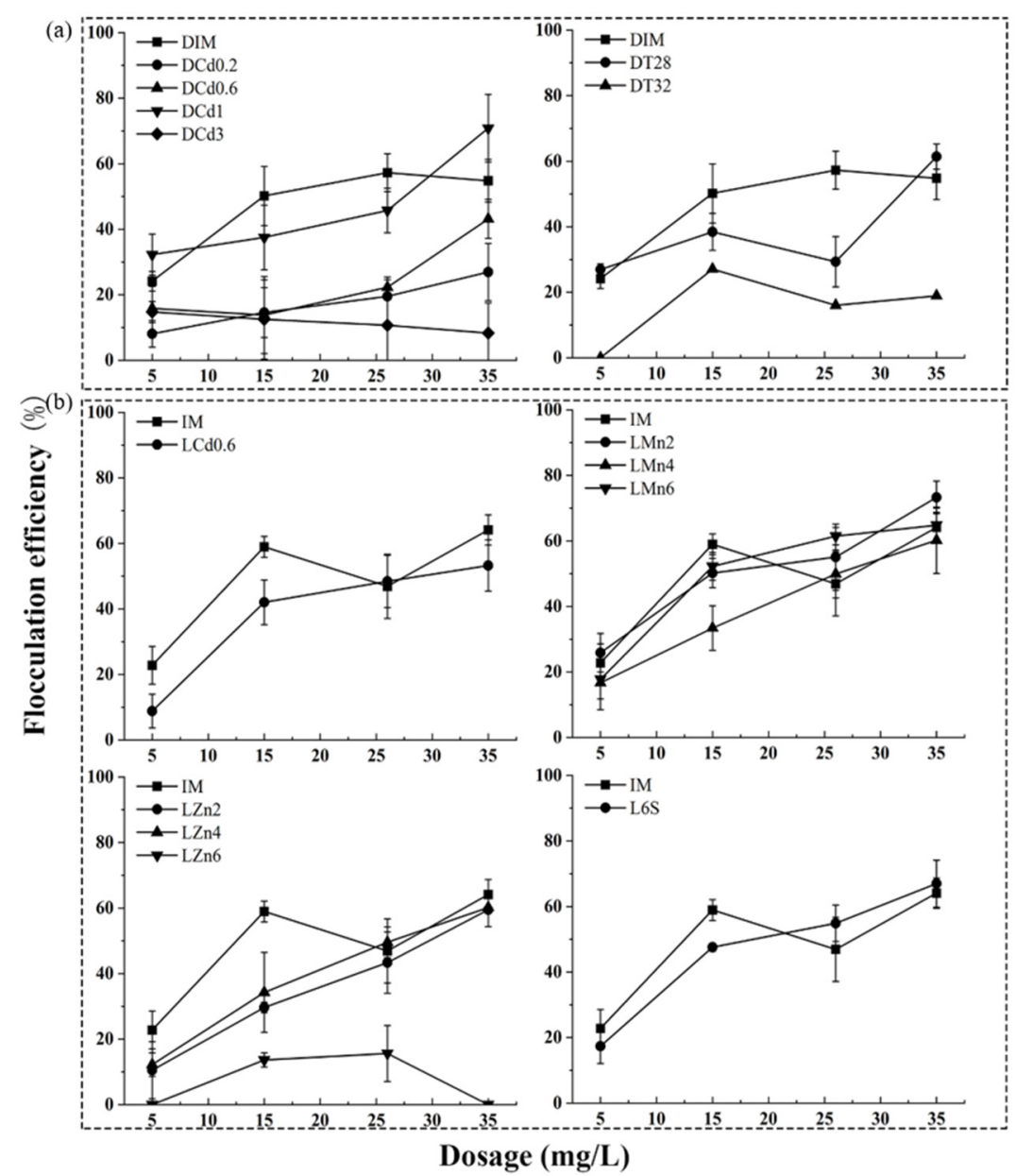

Figure 2. Bio-flocculation ability analysis of different freeze-dried algae powder samples of UTEX 2341. Flocculation efficiency of freeze-dried algae samples under different culture conditions without light (a) and with light (b).

\subsection{Effects of $p H$ on Flocculation Efficiency}

As shown in Figure 3, the four samples of DIM, DCd1, DT28, and L6S flocculated at $\mathrm{pH} 3.0-9.0$ and achieved their maximum flocculating rates of $80.19 \%, 83.79 \%, 73.67 \%$, and $79.24 \%$ respectively at $\mathrm{pH} 8.0$ (Figure $3 \mathrm{a}$ ). The maximum flocculating rates of another four samples of IM, LCd0.6, LZn2, and LMn2 were $47.75 \%, 33.49 \%, 63.62 \%$, and $71.63 \%$ respectively at $\mathrm{pH}$ 3.0. With the $\mathrm{pH}$ increased, the rates decreased gradually and no flocculation was observed at $\mathrm{pH}$ above 7 (Figure $3 \mathrm{~b}$ ). These results indicated that $\mathrm{pH}$ had an important effect on flocculation ability. Many studies have reported adjusting $\mathrm{pH}$ to flocculate microalgae. The flocculating rates of freshwater microalgae C. vulgaris, Scenedesmus sp. and Chlorococcum sp. were $90 \%$ at $\mathrm{pH} 10.6$ [39]. The rate of Chaetoceros densus ranged from 13\% to $82 \%$ as $\mathrm{pH}$ increased from 8.0 to 10.0 [28]. It had been widely accepted that microalgae cells are negatively charged, and microalgae excrete EPS into the medium in the growth process, resulting in different charges on the cell surface [40]. The flocculation changes induced by $\mathrm{pH}$ were a result of charge interaction. The optimum $\mathrm{pH}$ values for the eight samples in this study were also different and it was hypothesized that charge on the cell surface and the constitution of EPS changed under different culture conditions. 


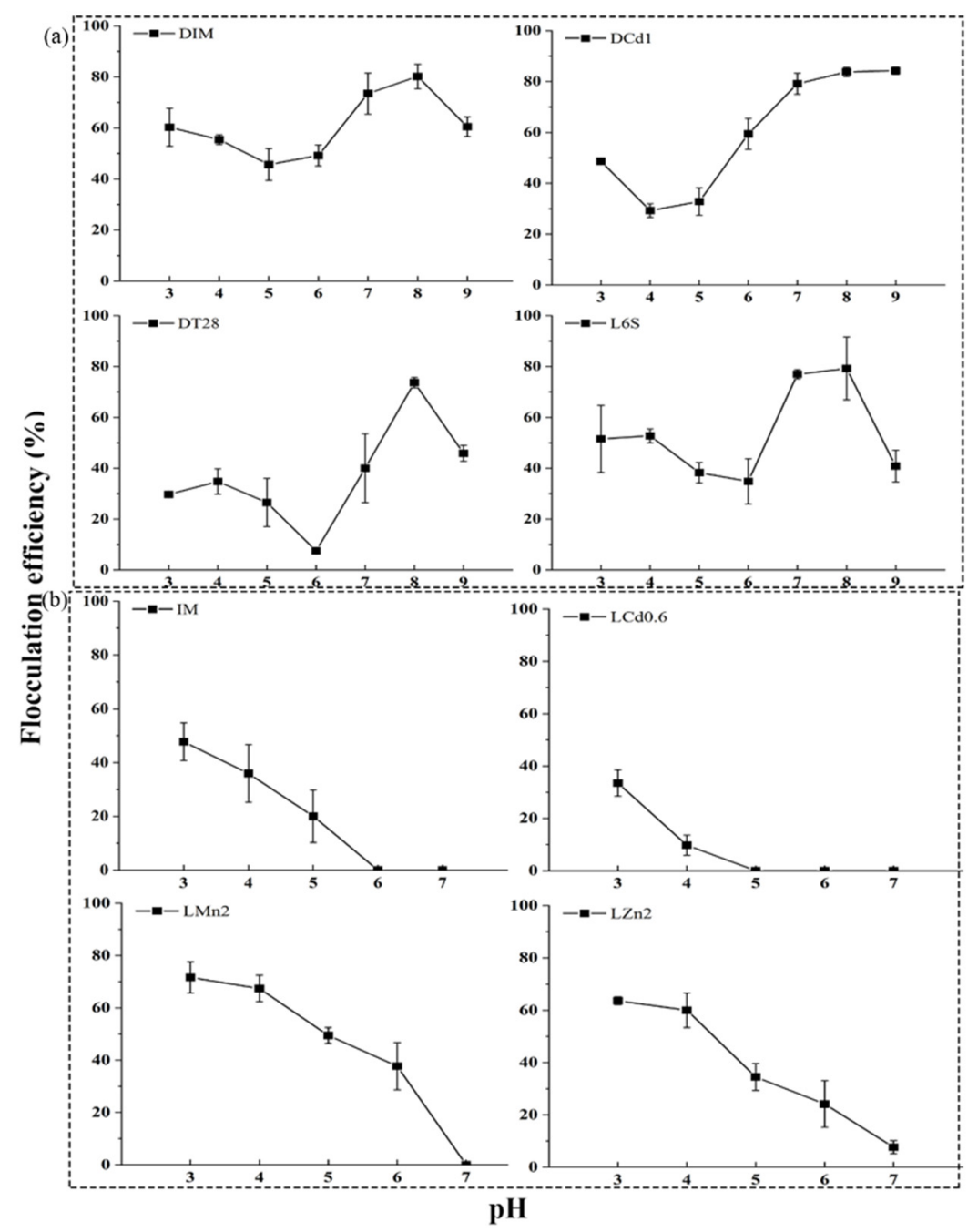

Figure 3. Effects of $\mathrm{pH}$ on the flocculation efficiency of different freeze-dried algae samples. (a) Samples of DIM, DCd1, DT28, L6S; (b) Samples of IM, LCd0.6, LM2, Lzn2.

\subsection{Effects of Temperature on Flocculation Efficiency and the Analysis of Flocculant Composition}

Temperature was found to have a noticeable effect on microalgae flocculation. The selfflocculating rate of the four samples of DIM, DCd1, DT28, and L6S exhibited no changes with temperature increases (Figure 4a). Other samples of IM, LCd0.6, LZn2, and LMn2 showed an increase in flocculation efficiency with the temperature rising. The maximum flocculating rate was about $67 \%$ at $50{ }^{\circ} \mathrm{C}$ (Figure $4 \mathrm{~b}$ ). The flocculant constituents of the eight samples were tested and found to be different. The polysaccharide of the eight samples varied from $14.15 \%$ to $24.18 \%$ and the proteins were $2.55-3.91 \%$ (Figure 5).

The flocculants with polysaccharides as the main components had strong thermal stability, while flocculants composed mainly of proteins or nucleic acids showed instability [41]. Cultivation parameters, such as illumination, temperature, and nutrients could all significantly affect EPS production [35]. Moreover, Andreadakis et al. reported that the EPS composition and properties rather than its amount affected the aggregation of cells [42]. Though DIM, DCd1, DT28, and L6S had lower polysaccharide contents, their flocculating rates were thermostable. Therefore, it was speculated that polysaccharides might have played a major role in their flocculation. Furthermore, Figures 2 and 5 show that light had little effects on the biomass and polysaccharide content of microalgae, but the flocculation rate of microalgae cultured with light was significantly higher than that without light, which further indicated that the components of extracellular polysaccharide rather than the content of polysaccharide had a greater effect on flocculation. The func- 
tional groups such as hydroxyl and carboxyl groups in the polysaccharide acted as the binding sites to bridge the floc components, namely cellular, bio-organic and inorganic compounds during the flocculation process, which was considered the main mechanism of EPS flocculation (namely electrostatic bridging mechanism) [40,43,44]. However, further researches need to be carried out to gain insights into the detailed flocculation mechanism of the polysaccharide with different compositions. In all, due to the thermal and chemical stability of polysaccharide, it has the potential of being used together with other commercial chemical flocculants (such as $\mathrm{FeCl}_{3} \cdot 6 \mathrm{H}_{2} \mathrm{O}$, alum, and polyacrylamide, etc) and other biological flocculants (such as $\gamma$-polyglutamic acid, xanthan gum, and guar gum, etc) to improve the efficiency of wastewater treatment and has a good application prospect.

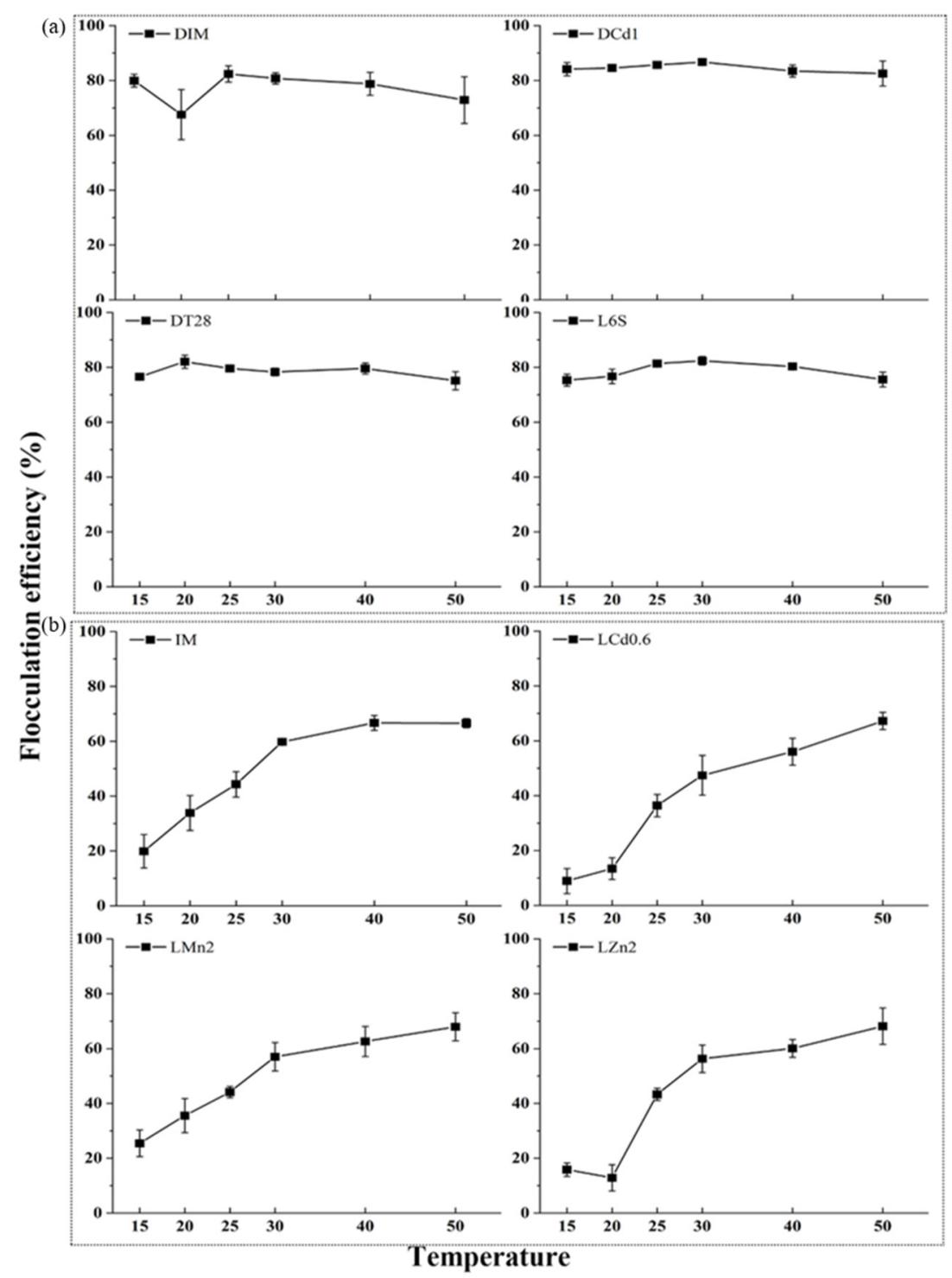

Figure 4. Effects of temperature on the flocculation efficiency of different freeze-dried algae samples. (a) Samples of DIM, DCd1, DT28, L6S; (b) Samples of IM, LCd0.6, LM2, Lzn2.

As can be seen from Figures 3 and 4, the flocculation rates of samples IM, LCd0.6, $\mathrm{LMn} 2$, and LZn2 decreased with $\mathrm{pH}$ increase and increased with temperature rise. Therefore, it could be concluded that the flocculation was not caused by polysaccharides and proteins, but other substances. The bio-flocculant produced by Shinella albus was proved to contain no proteins or polysaccharides but was characterized in composition to contain triple bonds and cumulated double bonds [6]. Therefore, the flocculation mechanism of samples IM, LCd0.6, LMn2, and LZn2 might be similar to that of Shinella albus, that is, 
charge neutralization mechanism (neutralizing the negative surface charge of microalgae by ion, polymer, or colloidal absorption) or sweeping flocculation mechanism (flocculation by massive precipitation of minerals). However, this hypothesis needs to be confirmed by more sufficient experiments in the future.

(a)

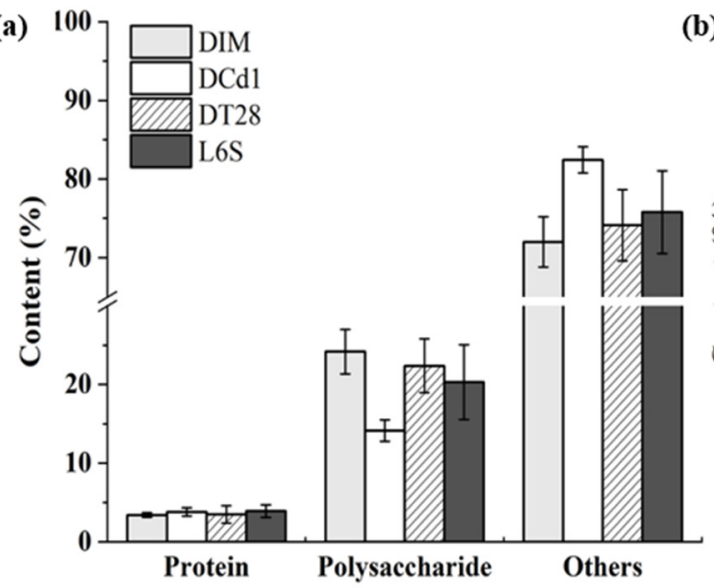

(b)

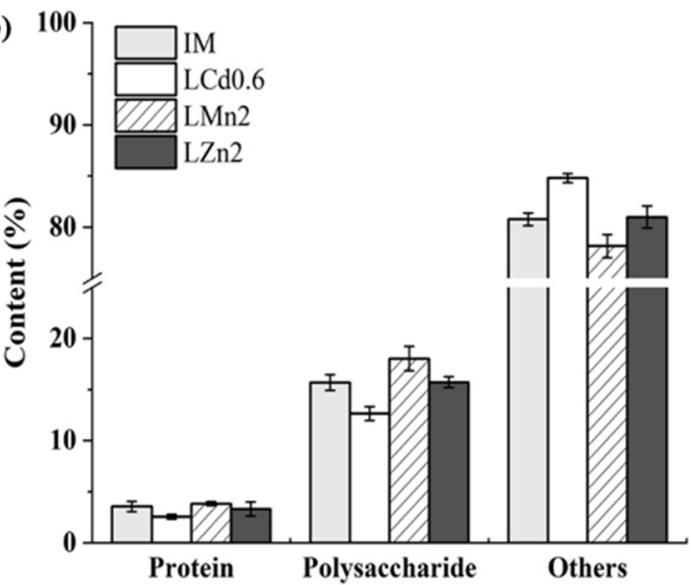

Figure 5. The analysis of flocculant compositions of different freeze-dried algae samples. (a) Samples of DIM, DCd1, DT28, L6S; (b) Samples of IM, LCd0.6, LM2, Lzn2.

\section{Conclusions}

This study confirmed that $A$. protothecoides UTEX 2341 cultured under heterotrophic and municipal wastewater conditions has a better self-flocculation ability of about $92 \%$ and $85 \%$, respectively, after $2 \mathrm{~h}$ of flocculation. Different stress culture conditions not only induced biomass and lipid content changes but also caused alterations in bio-flocculation efficiency. Algae cultured with light had better bio-flocculation efficiency than those cultured in the dark and $\mathrm{pH}$ affected the algae flocculation rate. The bio-flocculation rate of the samples IM, LCd0.6, LMn2, LZn2 increased with the temperature rising, while the samples of DIM, DCd1, DT28, and L6S remained stable with the temperature changing. Polysaccharides in IM, LCd0.6, LMn2, LZn2 might have played a major role in the flocculation, but flocculation in other samples might be caused by certain unknown matters. This study laid a solid foundation for the preliminary exploration of the flocculation properties of UTEX 2341, and in the future, more experiments about the characterization of EPS and other unknown matters need to be carried out to uncover the flocculation mechanism of A. protothecoides UTEX 2341.

Supplementary Materials: The following are available online at https:/ / www.mdpi.com/2071-105 0/13/5/2885/s1, Table S1: The details of freeze-dried algae samples $(18,19)$.

Author Contributions: Writing—Original Draft Preparation, J.L.; Writing—Review and Editing, J.Y.; Methodology, B.L. All authors have read and agreed to the published version of the manuscript.

Funding: This work was funded by the Second Tibetan Plateau Scientific Expedition and Research Program (STEP) grant number 2019QZKK0608.

Institutional Review Board Statement: Not applicable.

Informed Consent Statement: Not applicable.

Data Availability Statement: No new data were created or analyzed in this study. Data sharing is not applicable to this article.

Conflicts of Interest: The authors declare no conflict of interest. 


\section{References}

1. Kumar, M.; Sun, Y.; Rathour, R.; Pandey, A.; Thakur, I.S.; Tsang, D.C.W. Algae as potential feedstock for the production of biofuels and value-added products: Opportunities and challenges. Sci. Total Environ. 2020, 716, 137116. [CrossRef]

2. Marinello, S.; Gamberini, R.; Bastone, L. Experimental plant for the cultivation of microalgae in photobioreactors for energy production. In Proceedings of the 24th Summer School Francesco Turco, Brescia, Italy, 11-13 September 2019.

3. Liu, J.; Zhu, Y.; Tao, Y.; Zhang, Y.; Li, A.; Li, T.; Sang, M.; Zhang, C. Freshwater microalgae harvested via flocculation induced by pH decrease. Biotechnol. Biofuels. 2013, 6, 1-11. [CrossRef]

4. Ortiz, A.; García-Galán, M.J.; García, J.; Díez-Montero, R. Optimization and operation of a demonstrative full scale microalgae harvesting unit based on coagulation, flocculation and sedimentation. Sep. Purif. Technol. 2021, 259, 118171. [CrossRef]

5. Vasistha, S.; Khanra, A.; Clifford, M.; Rai, M.P. Current advances in microalgae harvesting and lipid extraction processes for improved biodiesel production: A review. Renew. Sustain. Energy Rev. 2021, 137, 110498. [CrossRef]

6. Li, Y.; Xu, Y.; Liu, L.; Jiang, X.; Zhang, K.; Zheng, T.; Wang, H. First evidence of bioflocculant from Shinella albus with flocculation activity on harvesting of Chlorella vulgaris biomass. Bioresour. Technol. 2016, 218, 807-815. [CrossRef] [PubMed]

7. Kim, J.; Ryu, B.G.; Kim, K.; Kim, B.K.; Han, J.I.; Yang, J.W. Continuous microalgae recovery using electrolysis: Effect of different electrode pairs and timing of polarity exchange. Bioresour. Technol. 2012, 123, 164-170. [CrossRef] [PubMed]

8. Vandamme, D.; Foubert, I.; Muylaert, K. Flocculation as a low-cost method for harvesting microalgae for bulk biomass production. Trends Biotechnol. 2013, 31, 233-239. [CrossRef]

9. Lee, Y.C.; Kim, B.; Farooq, W.; Chung, J.; Han, J.I.; Shin, H.J.; Jeong, S.H.; Park, J.Y.; Lee, J.S.; Oh, Y.K. Harvesting of oleaginous Chlorella sp. by organoclays. Bioresour. Technol. 2013, 132, 440-445. [CrossRef]

10. Schenk, P.M.; Thomas-Hall, S.R.; Stephens, E.; Marx, U.C.; Mussgnug, J.H.; Posten, C.; Kruse, O.; Hankamer, B. Second Generation Biofuels: High-Efficiency Microalgae for Biodiesel Production. Bioenergy Res. 2008, 1, 20-43. [CrossRef]

11. Griffiths, M.J.; Harrison, S.T.L. Lipid productivity as a key characteristic for choosing algal species for biodiesel production. J. Appl. Phycol. 2009, 21, 493-507. [CrossRef]

12. Salim, S.; Vermue, M.H.; Wijffels, R.H. Ratio between autoflocculating and target microalgae affects the energy-efficient harvesting by bio-flocculation. Bioresour. Technol. 2012, 118, 49-55. [CrossRef]

13. Wang, H.; Laughinghouse, H.D.T.; Anderson, M.A.; Chen, F.; Willliams, E.; Place, A.R.; Zmora, O.; Zohar, Y.; Zheng, T.; Hill, R.T. Novel bacterial isolate from Permian groundwater, capable of aggregating potential biofuel-producing microalga Nannochloropsis oceanica IMET1. Appl. Environ. Microbiol. 2012, 78, 1445-1453. [CrossRef] [PubMed]

14. Zhang, J.; Hu, B. A novel method to harvest microalgae via co-culture of filamentous fungi to form cell pellets. Bioresour. Technol. 2012, 114, 529-535. [CrossRef] [PubMed]

15. Yang, Q.; Xu, W.; Luan, T.; Pan, T.; Yang, L.; Lin, L. Comparative responses of cell growth and related extracellular polymeric substances in Tetraselmis sp. to nonylphenol, bisphenol A and $17 \alpha$-ethinylestradiol. Environ. Pollut. 2021, 274, 116605. [CrossRef]

16. Rashid, N.; Nayak, M.; Lee, B.; Chang, Y.-K. Efficient microalgae harvesting mediated by polysaccharides interaction with residual calcium and phosphate in the growth medium. J. Clean. Prod. 2019, 234, 150-156. [CrossRef]

17. Ummalyma, S.B.; Gnansounou, E.; Sukumaran, R.K.; Sindhu, R.; Pandey, A.; Sahoo, D. Bioflocculation: An alternative strategy for harvesting of microalgae-An overview. Bioresour. Technol. 2017, 242, 227-235. [CrossRef] [PubMed]

18. Cao, J.; Yuan, H.; Li, B.; Yang, J. Significance evaluation of the effects of environmental factors on the lipid accumulation of Chlorella minutissima UTEX 2341 under low-nutrition heterotrophic condition. Bioresour. Technol. 2014, 152, 177-184. [CrossRef]

19. Xing, G.; Yuan, H.; Yang, J.; Li, J.; Gao, Q.; Li, W.; Wang, E. Integrated analyses of transcriptome, proteome and fatty acid profilings of the oleaginous microalga Auxenochlorella protothecoides UTEX 2341 reveal differential reprogramming of fatty acid metabolism in response to low and high temperatures. Algal Res. 2018, 33, 16-27. [CrossRef]

20. Lu, J.; Ma, Y.; Xing, G.; Li, W.; Kong, X.; Li, J.; Wang, L.; Yuan, H.; Yang, J. Revelation of microalgae's lipid production and resistance mechanism to ultra-high Cd stress by integrated transcriptome and physiochemical analyses. Environ. Pollut. 2019, 250, 186-195. [CrossRef]

21. Li, C.; Yang, J.; Wang, X.; Wang, E.; Li, B.; He, R.; Yuan, H. Removal of nitrogen by heterotrophic nitrification-aerobic denitrification of a phosphate accumulating bacterium Pseudomonas stutzeri YG-24. Bioresour. Technol. 2015, 182, 18-25. [CrossRef]

22. Liu, W.; Wang, K.; Li, B.; Yuan, H.; Yang, J. Production and characterization of an intracellular bioflocculant by Chryseobacterium daeguense W6 cultured in low nutrition medium. Bioresour. Technol. 2010, 101, 1044-1048. [CrossRef]

23. Albalasmeh, A.A.; Berhe, A.A.; Ghezzehei, T.A. A new method for rapid determination of carbohydrate and total carbon concentrations using UV spectrophotometry. Carbohydr. Polym. 2013, 97, 253-261. [CrossRef]

24. Zhu, N.; Liu, J.; Yang, J.; Lin, Y.; Yang, Y.; Ji, L.; Li, M.; Yuan, H. Comparative analysis of the secretomes of Schizophyllum commune and other wood-decay basidiomycetes during solid-state fermentation reveals its unique lignocellulose-degrading enzyme system. Biotechnol. Biofuels 2016, 9, 2-22. [CrossRef]

25. Halfhide, T.; Dalrymple, O.K.; Wilkie, A.C.; Trimmer, J.; Gillie, B.; Udom, I.; Zhang, Q.; Ergas, S.J. Growth of an Indigenous Algal Consortium on Anaerobically Digested Municipal Sludge Centrate: Photobioreactor Performance and Modeling. Bioenergy Res. 2014, 8, 249-258. [CrossRef]

26. Wang, M.; Yang, H.; Ergas, S.J.; van der Steen, P. A novel shortcut nitrogen removal process using an algal-bacterial consortium in a photo-sequencing batch reactor (PSBR). Water Res. 2015, 87, 38-48. [CrossRef] [PubMed] 
27. Wang, Y.; Guo, W.; Yen, H.-W.; Ho, S.-H.; Lo, Y.-C.; Cheng, C.-L.; Ren, N.; Chang, J.-S. Cultivation of Chlorella vulgaris JSC-6 with swine wastewater for simultaneous nutrient/COD removal and carbohydrate production. Bioresour. Technol. 2015, 198, 619-625. [CrossRef]

28. Zuharlida, T.H.; Fatimah, M.Y.; Mohd, S.M.; Mohamed, S.M.D.; Arbakariya, B.A. Effect of different flocculants on the flocculation performance of microalgae, Chaetoceros calcitrans, cells. Afr. J. Biotechnol. 2009, 8, 5971-5978. [CrossRef]

29. Zhu, C.; Zhang, R.; Cheng, L.; Chi, Z. A recycling culture of Neochloris oleoabundans in a bicarbonate-based integrated carbon capture and algae production system with harvesting by auto-flocculation. Biotechnol. Biofuels 2018, 11, 204. [CrossRef] [PubMed]

30. Pérez, L.; Salgueiro, J.L.; Maceiras, R.; Cancela, Á.; Sánchez, Á. An effective method for harvesting of marine microalgae: pH induced flocculation. Biomass Bioenergy 2017, 97, 20-26. [CrossRef]

31. Ndikubwimana, T.; Zeng, X.; Murwanashyaka, T.; Manirafasha, E.; He, N.; Shao, W.; Lu, Y. Harvesting of freshwater microalgae with microbial bioflocculant: A pilot-scale study. Biotechnol. Biofuels 2016, 9, 47. [CrossRef]

32. Taylor, R.L.; Rand, J.D.; Caldwell, G.S. Treatment with algae extracts promotes flocculation, and enhances growth and neutral lipid content in Nannochloropsis oculata-a candidate for biofuel production. Mar. Biotechnol. 2012, 14, 774-781. [CrossRef] [PubMed]

33. Fan, G.; Lin, J.; Xia, M.; Luo, J.; Du, B.; Pang, H.; Yan, Z. Impact of Extracellular Polymeric Substance in the Inactivation of Harmful Algae by $\mathrm{Ag}_{2} \mathrm{O} / \mathrm{g}-\mathrm{C}_{3} \mathrm{~N}_{4}$ under Visible Light. Part. Part. Syst. Charact. 2020, 38, 2000272. [CrossRef]

34. Pirhanov, A.; Bridges, C.M.; Goodwin, R.A.; Guo, Y.-S.; Furrer, J.; Shor, L.M.; Gage, D.J.; Cho, Y.K. Optogenetics in Sinorhizobium meliloti Enables Spatial Control of Exopolysaccharide Production and Biofilm Structure. ACS Synth. Biol. 2021, 10, 345-356. [CrossRef] [PubMed]

35. González-Fernández, C.; Ballesteros, M. Microalgae autoflocculation: An alternative to high-energy consuming harvesting methods. J. Appl. Phycol. 2012, 25, 991-999. [CrossRef]

36. Hanumanth Rao, N.R.; Yap, R.; Whittaker, M.; Stuetz, R.M.; Jefferson, B.; Peirson, W.L.; Granville, A.M.; Henderson, R.K. The role of algal organic matter in the separation of algae and cyanobacteria using the novel "Posi" —Dissolved air flotation process. Water Res. 2018, 130, 20-30. [CrossRef] [PubMed]

37. Oh, H.-M.; IEE, S.J.; Park, M.H.; Kim, H.S. Harvesting of Chlorella vulgaris using a bioflocculant from Paenibacillus sp. AM49. Biotechnol. Lett. 2001, 23, 1229-1234. [CrossRef]

38. Díaz-Santos, E.; Vila, M.; de la Vega, M.; León, R.; Vigara, J. Study of bioflocculation induced by Saccharomyces bayanus var. uvarum and flocculating protein factors in microalgae. Algal Res. 2015, 8, 23-29. [CrossRef]

39. Wu, Z.; Zhu, Y.; Huang, W.; Zhang, C.; Li, T.; Zhang, Y.; Li, A. Evaluation of flocculation induced by pH increase for harvesting microalgae and reuse of flocculated medium. Bioresour. Technol. 2012, 110, 496-502. [CrossRef] [PubMed]

40. Agbakpe, M.; Ge, S.; Zhang, W.; Zhang, X.; Kobylarz, P. Algae harvesting for biofuel production: Influences of UV irradiation and polyethylenimine (PEI) coating on bacterial biocoagulation. Bioresour. Technol. 2014, 166, 266-272. [CrossRef]

41. Takagi, H.; Kadowaki, K. Flocculant Production by Paecilomyces sp. Taxonomic Studies and Culture Conditions for Production. Agric. Biol. Chem. 2014, 49, 3151-3157. [CrossRef]

42. Andreadakis, A.D. Physical and chemical properties of activated sludge floc. Water Res. 1993, 27, 1707-1714. [CrossRef]

43. Shen, Y.; Fan, Z.; Chen, C.; Xu, X. An auto-flocculation strategy for Chlorella vulgaris. Biotechnol. Lett. 2015, 37, 75-80. [CrossRef] [PubMed]

44. Guo, S.L.; Zhao, X.Q.; Wan, C.; Huang, Z.Y.; Yang, Y.L.; Alam, M.A.; Ho, S.H.; Bai, F.W.; Chang, J.S. Characterization of flocculating agent from the self-flocculating microalga Scenedesmus obliquus AS-6-1 for efficient biomass harvest. Bioresour. Technol. 2013, 145, 285-289. [CrossRef] [PubMed] 